\title{
Analysis of Inflation Targets in Indonesia During The New Normal Era: New Consensus Approach to an Open Economy
}

\author{
Abdul Kadir Arno1, Ilham², Akbar Sabani3, Iksan Purnama4 \\ Faculty of Islamic Economics and Business, Palopo State Islamic Institute \\ Palopo, South Sulawesi \\ E-mail: abdulkadir.arno@iainpalopo.ac.id
}

\begin{abstract}
,
This article aims to discuss a growth model in terms of demand constrained by economic policy with inflation targeting in a super multiplier sraff model by analyzing how economic policy can affect productive capacity growth. This article also analyzes the open economy if inflation is a phenomenon resulting from the policy of the monetary authority that can manage the nominal exchange rate through changes in interest rates. Since the distribution of functional income will depend on the evolution of nominal wages, exchange rates and interest rates, we will show that the inflation targeting system, apart from being neutral in terms of long-term growth, can also produce different results in terms of the distribution of functional income
\end{abstract}

Keywords: Demand, growth, income distribution, inflation target

\section{INTRODUCTION}

At present, as an effect of the development of the globalization era, a country's economy will be increasingly integrated with other countries, both within one region and the world. The integration of these countries intended to increase cooperation between countries. Integration between countries in the economic field, commonly referred to as economic openness.

Economic openness is one of the impacts of globalization, so that various countries around the world have begun to integrate to improve conditions and increase the economic growth of their respective countries. According to Krisharianto et al., (2007), Ahmed et al., (2010); Jawas, (2008) and Shahzad, (2017) who show that the flow of foreign capital and international trade as a representation of economic openness can become a motor of economic growth.

Economic openness can provide opportunities to export goods whose production factors use abundant resources and import goods whose production factors are scarce or expensive if produced domestically. According to modern economic growth theory, economic openness believed to boost a country's economic growth. Economic openness can provide opportunities to export goods whose production factors use abundant resources and import goods whose production factors are scarce or expensive if produced domestically. According to modern economic growth theory, economic openness believed to be able to boost a country's economic growth.

According to research from Nowbutsing (2014), economic openness is a means to promote economic growth through research and development as well as broader market access. The principle of economic openness implemented by a country, including Indonesia, is currently experiencing disruption due to the Covid-19 pandemic outbreak, which was experienced by around 216 countries with 17,628,109 confirmed cases (Gugus Tugas, 2020). Although in the first few months of the 
outbreak of the COVID 19 pandemic, many research articles discussed only the health sector, including Bedford et al., (2020), Adams \& Walss, (2020), Holmes et al., (2020), Meng et al., (2020), Spinelli, (2020).

The Covid-19 pandemic has disrupted not only the health sector but also the economic activity and the business sector in an extreme way, especially the production sector, so that the chain of related sectors has also disrupted, some have even stagnated. Economist Faisal Basri said, as reported in Kontan online newspapers co.id. That there has been a supply shock and demand shock simultaneously due to the global Covid-19 pandemic, especially the upstream-downstream manufacturing sector, so that it has a significant impact on other sectors. To the extent that the financial sector experienced shocks, the stock market, and bond markets were also depressed, investment had almost stopped, and millions of workers had dismissed as this pandemic, not only Indonesia was experiencing, but all countries were also feeling the impact.

When businesses lose income, unemployment tends to rise sharply, turning supply-side shocks into broader demand-side shocks. The severity impact will largely depend on the duration of restrictions on the movement of people and economic activity, as well as on the scale and efficacy of the response by national financial authorities.

In dealing with Covid-19, the Government of Indonesia is taking a fast and prudent approach to reduce its impact economy. Some experts worry that the economic impact caused by Covid-19 could outweigh the health impacts, and economic growth will slow down. If there is an economic slowdown, the absorption of labor will decrease, increasing unemployment and poverty

As is well known, was had the sector hit by the Covid-19 pandemic was tourism due to travel restrictions and the consequences of social distancing. The impact spreads to the hotel, restaurant, retail, transportation, and other industries. Also, the tourism sector, the manufacturing sector is affected due constraints on the supply chain of raw materials due to scarcity of raw materials and delays in the arrival of raw materials, especially from countries that are suppliers that are also affected by the COVID 19 pandemic will have an impact on rising product prices and triggering inflation.

Therefore, to anticipate the occurrence of very high inflation, the government should be able to issue policies to anticipate this. One of the policies that can be taken by the government is the policy in the monetary sector. Monetary policy is a set of economic policies that regulate the size and rate of growth of the money supply in a country's economy. This policy is a measurable measure to regulate macroeconomic variables such as inflation and unemployment. The monetary policy implemented in several ways, including adjusting interest rates, buying or selling government securities, and changing the amount of cash circulating in the market. The central bank or regulatory body responsible for this matter has the right to formulate this policy. In Indonesia, monetary policy is regulated solely by the central bank, namely Bank Indonesia 
The impact of monetary policy on economic growth in real terms has become an area of debate in macroeconomics (Bernanke \& Gertler, 1995). Many studies have attempted to identify it to uncover the problem of the impact of monetary policy. For example, (Carlino, 1999), and Owyang \& Wall, (2005) studied in the United States, while (Ramaswamy \& Slok, 1998) and (Clements et al., 2001) have studied European countries. In general, their findings show different effects in response to monetary policy, (Tillmann, 2019), (Beutler et al., 2020), (Carlino, 1999),(Gertler \& Karadi, 2015),(Hanson et al., 2014).

The monetary policy taken by the government in Indonesia must be in line with fiscal policy in minimizing the impact of Covid-19 on the national economy. Therefore, the monetary authority must maintain the rupiah exchange rate, control inflation, and provide a monetary stimulus for the business world. In connection with the COVID-19 pandemic conditions and the principle of economic openness, monetary policy also has implications for the exchange rate. Therefore, raising or lowering the BI rate has implications not only for inflation but also for growth and the exchange rate.

At this time, the community was the condition that requires people to adapt Covid-19, which referred to as the New Normal period. Due to these conditions concerning economic problems, especially those related to the possible impact of the Covid-19 Pandemic, namely the possibility of an increase in product prices and a decrease in public purchasing power which could trigger inflation, according to the author's opinion, it would be appropriate if a new consensus model is needed-related to the targeting of a specific inflation rate in an open economy system that is widely used by a country today.

The consensus model with inflation targeting as an alternative calculation is based on a theoretical structure, namely (i) the potential output or productive capacity of the economy following expected long-term sufficient demand ii) productive output depending on the real interest rate (stimulating investment spending), (iii) the existence of the Phillips curve as an accelerator (iv) the nominal exchange rate depends on the difference in interest rates and (v) the response of the Monetary Authority through the nominal interest rate to inflation deviations from its potential target and output.

However, there is a large amount of work that critically evaluates new consensus models in a closed economy context. They show that by changing some of the hypotheses of this model (such as the accelerationist Phillps curve), different results can emerge concerning output, productive capacity and inflation dynamics (Setterfield, 2004; Lavoie and Kriesler, 2007; Lavoie, 2006; Atesoglu and Smithin, 2006; Serrano, 2006; Aspromourgos, 2007; Setterfield, 2015). For an open economy, we have several examples of alternative models, such as Cordero (2008) and Vera (2014).

This article seeks to analyze a new macroeconomic consensus model for calculating the inflation target in Indonesia and analyzing the determinants of inflation in the long run so that the monetary authorities can manage and calculate the inflation target in the following years. 


\section{LITERATURE REVIEW Inflation}

A country's economy can be said to be healthy if its economic growth is stable and shows a positive direction, as reflected in macroeconomic activities. One of the macroeconomic indicators to see the stability of a country's economy is inflation. From an economic perspective, inflation is a monetary phenomenon in a country where the ups and downs of inflation tend to cause economic turmoil because inflation affects economic growth, the international trade balance, the value of inter-state debt, interest rates, domestic savings, unemployment, and social welfare.

Initially, inflation defined an increase in circulation or an increase in liquidity in an economy. This definition refers to general symptoms caused by an increase in the money supply, which thought to have caused an increase in prices. In a further development, inflation can briefly be interpreting as a tendency to increase the prices of goods and services in general and continuously. Economists define inflation differently but have the same core, namely the increase in prices which tend to rise continuously.

Monetary thinking argues to the extreme that "inflation anywhere and anytime is a monetary phenomenon arising from the excess money supply (Budiono, 1985)." Inflation is the process of increasing the general prices of goods continuously within a specified period. The increase that occurred only once (although with a reasonably large percentage) was not inflation (Nopirin, 2000).

Inflation is like a ghost that lurks an economy where its movements are difficult to predict, so it is exciting to discuss its full impact. Inflation is like a scourge in developing countries like Indonesia, with an agrarian-style economic structure. Inflation will not be a significant problem if this condition is accompanying by the availability of the required commodities and is accompanying a more significant increase in the level of income. The production cost to produce a commodity is getting higher, which causes the selling price to be relatively high. On the other hand, the level of community income is relatively fixed. Inflation is like a double-edged sword where one side can provide an advantage on the other. Inflation is like a spring that must be maintained if its flexibility is too high, it can endanger economic growth, but on the other hand, if it is too low, it will cause an economic downturn and will not provide a stimulant for the real sector to carry out production activities.

Since inflation is an increase in the prices of goods and services in general, an index figure used to measure changes in inflation from time to time. The index figure compiled by taking into account several goods and services used to calculate the amount of inflation. The change index number from one time another, expressed as a percentage, is the amount of inflation in that period.

The complexity calculating index number is related not only to the types of goods and services that need to included in the inflation calculation but also the weight of each good and services calculated in inflation. The inflation rate is, of course, calculated for different purposes of analysis. To meet these different needs, are several types of inflation rates. In practice, there are several types of inflation rates. The 
inflation rate that is most common and widely known by the public is the inflation rate to calculate changes in the price of goods and services consumed by society. The inflation rate is calculated based on an index number compiled from the prices of goods and services consumed by the public and is known as the Consumer Price Index (CPI).

Several studies have examined the inflation term in the world, (Carrasco et al., 2015), (Saraswat \& Sundrum, 2015), (Marco et al., 2015), (Oda, 2015), (Heidenreich et al., 2015), (Kallosh \& Linde, 2015), (Kearney et al., 2015), (Malmendier \& Nagel, 2015), (Motohashi et al., 2015).

Inflation arises from pressure from the supply side (cost-push inflation), from the demand side (demand-pull inflation), and inflation expectations. The factors of cost-push inflation can be caused by exchange rate depreciation, the impact of foreign inflation, especially trading partner countries, increases in government-regulated commodity prices (administered prices), and adverse supply shocks due to natural disasters and disruption of distribution.

The factor that causes demand-pull inflation is the high demand for goods and services relative to their availability. In the macroeconomic context, this condition by the real output that exceeds potential output or total demand (aggregate demand) is more excellent than the economy's capacity. Meanwhile, the inflation expectation factor is influenced by the behavior of the public and economic actors in inflation rate expectations in their decisions on economic activities. Inflation expectations tend to be adaptive or forward-looking. This is reflected in the behavior of price formation at the producer and trader levels, especially in the lead-up to religious holidays (Eid, Christmas, and New Year) and the determination of the provincial minimum wage (UMP). Although the general availability of goods is estimated to be sufficient to support the increase in demand, the price of goods and services during religious holidays increases higher than the supply-demand condition. Likewise, at the time of determining the UMP, traders also increased the price of goods even though the wage increase was not significant in driving an increase in demand.

The indicator that is often used to measure the inflation rate is the Consumer Price Index (CPI). Changes in the CPI from time to time indicate the price movements of packages of goods and services consumed by the public. The CPI basket's determination of goods and services is carried out based on the Cost of Living Survey (SBH) conducted by the Central Statistics Agency (BPS). Then, BPS will monitor the price development of these goods and services every month in several cities, in traditional and modern markets for several types of goods/services in each city.

BPS currently also publishes inflation based on another grouping called inflation disaggregation. The disaggregation of inflation is carried out to produce an inflation indicator that is more representative of the influence of fundamental factors. In Indonesia, the CPI inflation disaggregation is grouped into core inflation and non-core inflation. 
- Core Inflation,

Non-core inflation is a component of inflation that tends to stay or is persistent (persistent component) in the inflationary movement and is influenced by fundamental factors, such as 1) demand-supply interactions, 2) external environment: exchange rates, international commodity prices, trading partner inflation, 3) Inflation expectations from traders and consumers

- Non-core inflation,

Non-core inflation is a component of inflation that tends to be highly volatile because it is influenced by other than fundamental factors. Non-core inflation components consist of: a) Volatile Food Component Inflation: Shocks predominantly influence inflation in the foodstuff group such as harvests, natural disturbances, or development factors in domestic food commodity prices as well as developments in international food commodity prices, b) Government-regulated Price Component Inflation (Administered Prices): Inflation is predominantly affected by shocks in the form of Government pricing policies, such as subsidized fuel prices, electricity rates, transportation rates, etc.

In the Indonesian context, the inflation target or target is the inflation rate that must be achieved by Bank Indonesia, in coordination with the Government. The inflation target is set based on the Law on Bank Indonesia by the Government. In the Memorandum of Understanding between the Government and Bank Indonesia, the inflation target is set for the next three years through a Minister of Finance Regulation (PMK). Currently, the inflation target and rate in Indonesia are set based on PMK No.93 / PMK.011 / 2014 concerning 2016, 2017 and 2018 Inflation Target dated 21 May 2014, the inflation target set by the Government for the 2016 - 2018 period, respectively $4 \%, 4 \%$, and $3.5 \%$, with a deviation of $\pm 1 \%$, respectively. Meanwhile, the 2019-2021 inflation target is set based on the Minister of Finance Regulation No. 124 / PMK.010 / 2017, respectively 3.5\%, 3.0\%, and 3.0\%, with a deviation of $\pm 1 \%$ respectively. It is hoped that the inflation target will serve as a reference for business actors and the public in carrying out future economic activities so that the inflation rate can be reduced to a low and stable level. Bank Indonesia and the Government remain committed to achieving the set inflation target through policy coordination consistent with the inflation target. One of the efforts to control inflation towards low and stable inflation is to form and direct public inflation expectations so that they refer to (anchor) the inflation target that has been set. \%. (See Minister of Finance Regulation on inflation targets for 2016, 2017, and 2018 and Minister of Finance Regulation on inflation targets for 2019, 2020, and 2021)

\section{New Consensus Inflation Target}

In an open economic context, the new consensus model states that Real Interest Rate Parity applies (Romer, 2006). It implied by this assumption that Interest Rate Parity applies in the short run by individuals operating in the exchange rate market having Rational Expectations and believing that Purchasing Power Parity persists in 
the long run (Lavoie, 2000). Summa, (2016) states that the new consensus growth model due to aggregate demand by economic policies and constraints on the evolution of state financial conditions, general market conditions, and general inflation conditions.

Goodfriend and King proposed four elements essential to the new consensus theory: optimization over time, rational expectations, imperfect competition, and costly price adjustments. Goodfriend and King also found that consensus models produce specific policy implications. Contrary to some new classical thinking, monetary policy can affect real output in the short run. However, there is no long-run trade-off Goodfriend adds that money is not neutral in the short-run money will be neutral in the long run, inflation has a negative welfare impact, so it is vital for banks central to maintaining credibility through regulation-based policies such as inflation targeting.

There is a large amount of work that critically evaluates new consensus models in a closed economy context. They show that by changing some of the hypotheses of this model (such as the accelerationist Phillps curve), different results can emerge concerning output, productive capacity and inflation dynamics (Setterfield, 2004; Lavoie and Kriesler, 2007; Lavoie, 2006; Atesoglu and Smithin, 2006; Serrano, 2006; Aspromourgos, 2007; Setterfield, 2015). For an open economy, we have several examples of alternative models, such as Cordero (2008) and Vera (2014).

The consensus model with inflation targeting as an alternative calculation is based on a theoretical structure, namely (i) the potential output or productive capacity of the economy following expected long-term sufficient demand ii) productive output depending on the real interest rate (stimulating investment spending), (iii) the existence of the Phillips curve as an accelerator (iv) the nominal exchange rate depends on the difference in interest rates and (v) the response of the Monetary Authority through the nominal interest rate to inflation deviations from its potential target and output.

\section{Gross Domestik Product (GDP) Potensial}

Potential GDP refers to the maximum output that an economy can produce with the resources it has. This term also refers to total output at full capacity. At this level, the economy fully utilizes all of its resources and works in full employment. GDP potential can increase due to the increase in production factors and technological progress, and the increase will not result in inflation pressure on the economy. They are also known as potential output, GDP at full employment, long-run output.

Potential GDP measures the highest value of real GDP. Meanwhile, actual real GDP refers to the actual output of goods and services in a particular year, as reported by the Central Bureau of Statistics every quarter. Actual GDP can change due to changes in aggregate demand and short-run aggregate supply, or changes in the determinants of potential GDP. Meanwhile, the potential increase in GDP occurs due to changes in the following factors of production: (i) Growth in the supply of labor (ii) Improved quality of human capital, which makes labor more productive (iii) Growth 
in capital stock, (iv) Advances in technology, (v) Increased availability of natural resources.

In the short run, actual real GDP can be above, below, or just above potential GDP. We call the output gap (the output gap or GDP gap) the difference in value between actual real GDP and potential GDP. The output gap can be positive or negative. It is positive if actual real GDP is above potential GDP. We call this the inflationary gap or expansionary gap.

\section{Expenditure Output Growth}

Autonomous expenditures refer to expenses that are not affected by the level of income. In other words, this expense will remain even if the income is equal to zero. For individuals, some basic needs, such as food and drink, fall into this expenditure category. Meanwhile, in macroeconomics, the primary examples are government spending, specific investment spending, and exports. Also known as autonomous consumption.

Free spending does not change due to fluctuations in real GDP but is determined by external factors such as interest rates and economic policies. Economists classify aggregate expenditures into two broad categories: induced expenditures and autonomous expenditures.

Induced expenditure fluctuates with changes in aggregate income, as indicated by changes in real GDP. When real GDP rises, induced spending will also increase. Vice versa, its value will decrease when real GDP falls. On the other hand, freespending does not depend on fluctuations in real GDP. The value is constant, even if real GDP is zero. In a curve, the value represents the intercept of a linear aggregate expenditure curve.

In macroeconomics, aggregate expenditure represents total expenditure by four economic sectors: household, government, business, and external. Not all expenditure from the four sectors is induced expenditure. For example, government spending, unlike tax revenue, is not linked to economic growth. On the contrary, it depends on government policy. Likewise, with exports, fluctuations do not depend on the domestic economy but for global economic growth and trading partners. Therefore, government spending and exports are autonomous spendings

\section{Real Interest Rate}

In-Law no. 23 of 1999 concerning Bank Indonesia stipulates that the objective of Bank Indonesia is to achieve and maintain the stability of the Rupiah. The stability of the Rupiah value includes the stability of goods and services, which is reflected in the development of the inflation rate and the stability of other countries' currencies as measured by the development of the rupiah exchange rate against the currencies of other countries.

The rate of inflation is determined by the forces of supply and demand, which reflect the behavior of market participants or society. One of the factors that influence people's behavior is their expectation of future inflation rate. The expectation of a high inflation rate will encourage people to shift their financial assets into real assets such 
as land, houses, and other consumer goods. Vice versa, expectations of low inflation rates will provide incentives for people to save and invest in productive sectors.

Public expectations of future inflation can be seen, among others, from developments in nominal bank interest rates. This is in line with the point of view of the term structure theory, which states that people's expectations of future inflation can be seen from developments in nominal interest rates. In general, nominal interest rates reflect real interest rates plus inflation expectations. Thus, developments in the nominal interest rate can be used as an indicator of public inflation expectations.

One way of looking at inflation expectations in nominal interest rates is by using a yield curve. Yield Curve is the relationship between income or interest rate (rate of return) and term of maturity. The yield curve is related to the monetary policy transmission mechanism. Conventionally, the transmission of monetary policy occurs from short-term interest rates controlled by the central bank to long-term interest rates. Long-term interest rates will, in turn, affect aggregate demand. Central banks in countries that use inflation as the final target can use long-term interest rates to test the effectiveness of their achievement in controlling low inflation. Several empirical studies in the United States and several other countries have found a close relationship between the slope of the interest rate period over one year and the projected inflation in the medium term. (Jim and Ron Lange, 1997). The theoretical framework related to this is the "Fisher Hypothesis," which states that nominal interest rates have a onefor-one relationship with inflation expectations.

\section{Philips Curve Accelerator}

The Phillips curve states that low inflation is often followed by high unemployment, and vice versa if low unemployment can be achieved with higher inflation. Each country expects to reach the stage of economic activity at the level of full employment without inflation. However, in practice, this is not easy to do. Economists have realized that, if the unemployment rate is low, inflation will be even more severe. Meanwhile, if there is a severe unemployment problem, the level of prices is relatively stable. This means that it is not easy to create full employment and price stability simultaneously.

A.W. Phillips (1958) in Mankiw (2000) describes how the distribution of the relationship between inflation and the unemployment rate is based on the assumption that inflation reflects an increase in aggregate demand. With an increase in aggregate demand, it follows the demand theory. That is, if demand increases, the price will increase.

With high prices (inflation), in order to meet the demand, producers increase their production capacity by increasing labor (labor is the only input that can increase output). As a result of the increase in demand for labor, with rising prices (inflation), unemployment decreases. The shape of the Phillips curve has a decreasing slope, which indicates a negative relationship between changes in the wage rate and the unemployment rate, namely when the wage rate increases, unemployment is low, or vice versa. The Phillips curve proves that between price stability and high employment opportunities cannot coincide, which means that wanting to achieve high employment 
opportunities or low unemployment, as a consequence, must be willing to bear the burden of high inflation. In other words, this curve shows that there is a tradeoff (negative relationship) between inflation and the unemployment rate, that is, the unemployment rate can always be reduced by pushing the inflation rate up and that the inflation rate can always be reduced by allowing the unemployment rate to increase.

\section{Monetary Authority Response to Nominal Interest Rate}

This monetary policy transmission mechanism requires time (time lag). Time lag for each path can be different from the others. The exchange rate channel usually works faster because the impact of changes in interest rates on the exchange rate works very quickly. Conditions in the financial and banking sectors also greatly influence the speed of monetary policy transmission. If banks see that the economic risk is quite high, banks' response to the cut in the 7DRR BI interest rate is usually prolonged. If banks are consolidating to improve capital, lowering credit interest rates and increasing demand for credit will not necessarily be responded to by increasing lending. On the demand side, the decline in bank lending rates will not necessarily be responded to by increasing demand for credit from the public if the economic outlook is sluggish. In conclusion, conditions in the financial sector, banking sector, and real sector conditions play a significant role in determining whether or not the monetary policy transmission process will be sufficient.

The ultimate goal of monetary policy is to maintain and maintain the rupiah value's stability, one of which is reflected in the low and stable inflation rate. To this end, Bank Indonesia set the BI 7DRR policy interest rate as the main policy instrument to influence economic activity with the ultimate goal of achieving inflation. However, the path or transmission from the BI 7DRR decision to the achievement of the inflation target is very complex and requires time (time lag).

Changes in the 7DRR BI interest rate can also affect exchange rates. This mechanism is often called the exchange rate channel. An increase in the BI 7DRR, for example, will encourage an increase in the difference between interest rates in Indonesia and foreign interest rates. The widening of the interest rate differential encourages foreign investors to invest in Indonesia's financial instruments, such as SBIs because they will get a higher return rate. This foreign capital inflow will, in turn, encourage appreciation of the Rupiah exchange rate. Rupiah's appreciation causes the price of imported goods to be cheaper, and our export goods abroad become more expensive or less competitive, which will encourage imports and reduce exports. The decline in net exports will have an impact on decreasing economic growth and economic activity.

Changes in the 7DRR BI interest rate affect the macroeconomy through changes in asset prices. An increase in interest rates will lower the prices of assets such as stocks and bonds, thereby reducing the wealth of individuals and companies, which in turn reduces their ability to carry out economic activities such as consumption and investment. 
The mechanism by which the BI 7DRR changes to affect inflation is often referred to as the monetary policy transmission mechanism. This mechanism illustrates the actions of Bank Indonesia through changes in monetary instruments and their operational targets that affect various economic and financial variables before ultimately affecting the ultimate goal of inflation. This mechanism occurs through interactions between the Central Bank, banking, financial sectors, and the real sector. Changes in the BI 7 DRR affect inflation through various channels, including the interest rate channel, the credit line, the exchange rate channel, the asset price channel, and the expectation channel.

In the interest rate channel, changes in the BI 7DRR affect deposit rates and bank lending rates. If the economy is experiencing a downturn, Bank Indonesia can use an expansionary monetary policy through lowering interest rates to stimulate economic activity. The reduction in the $7 \mathrm{DRR}$ BI interest rate reduces the credit interest rate so that the demand for credit from companies and households increases. A reduction in loan interest rates will also reduce the cost of capital for companies to invest. All of this will increase consumption and investment activities so that economic activity will be more vibrant. Conversely, if inflationary pressure increases, Bank Indonesia will respond by raising the $\mathrm{BI} 7 \mathrm{DRR}$ interest rate to put a brake on economic activity that is too fast to reduce inflationary pressure.

The impact of changes in interest rates on economic activity also affects public expectations of inflation (the expectation line). The decline in interest rates is expected to stimulate economic activity, and ultimately inflation will encourage workers to anticipate rising inflation by asking for higher wages. This wage will ultimately be passed on by producers to consumers through price increases.

Bank Indonesia is strengthening the financial operation framework by implementing a new benchmark interest rate or policy interest rate, namely the 7-Day (Reverse) Repo Rate, which became effective on 19 August 2016, replacing the BI Rate. This strengthening of the financial operation framework is a common practice in various central banks and is an international best practice in monetary operations. The monetary operations framework is continually being refined to strengthen policies' effectiveness in achieving the set inflation target. The BI 7-day (Reverse) Repo Rate instrument is used as the new policy rate because it can quickly influence the money market, banking, and real sectors. The BI 7-Day Repo Rate instrument, as a new reference, has a stronger relationship to money market interest rates, is transactional or traded on the market, and encourages financial market deepening, particularly the use of the repo instrument.

With the BI 7-day (Reverse) Repo Rate instrument as the new policy rate, three main impacts are expected. First, strengthening monetary policy signals with the 7day (Reverse) Repo Rate as the primary reference on the financial market. Second, the increased effectiveness of monetary policy transmission through its influence on movements in money market interest rates and bank interest rates. Third, the formation of a more in-depth financial market, particularly transactions and the formation of an interest rate structure on the interbank money market (PUAB) for a tenor of 3-12 months. 


\section{METHODS}

The analytical method in the model article is in its simplest version, by running a numerical simulation to assess the behavior of several selected variables. The purpose of this is to:

1. Evaluate whether the results of the analytical solution are valid;

2. Evaluate the dynamic path in the direction (or not) to the equilibrium position;

3. Compare the different equilibrium positions when we change the parameters.

From the analytical model, we will assess the path results of

1. The growth rate of productive capacity and the distribution of functional income if we have (a) different inflation targets; (b) international inflation rate; (c) sovereign deployment.

2. We can also examine the hypothesis that, if the monetary authority controls the nominal interest rate, the monetary authority can control the inflation rate toward the target when core inflation is cost-push and related to imported inflation.

3. Finally, we will analyze the dynamic paths of real interest rates, real exchange rates, and the output gap associated with different inflation targets.

To assess the inflation target in this article, we use numerical simulation data, with the extreme hypothesis $h=1$ in that adaptive exchange rate expectations are ignored, and current exchange rate expectations depend on the average weight of past exchange rates. The initial conditions, parameters and expected exogenous variables are: (a) inflation starts at 6\%; (b) the first expected exchange rate is 4.0 and parameter $\mathrm{h}$ is 0.76 ; (c) $5 \%$ international interest rate and $2 \%$ sovereign spread; (d) the initial nominal domestic interest rate is $20 \%$; (d) The initial rates of output and productive capacity are in equilibrium and equal to 400; (e) The exogenous component of the growth rate for autonomous expenditure, $\mathrm{s}$ is $8 \%$; (f) The parameter of monetary authority rule $\gamma$ is 0.7 ; $(\mathrm{g})$ a high $\mathrm{d}$ value, indicating that short-term capital flows are very sensitive to differences in interest rates. All simulations start with the same initial conditions.

\section{DISCUSSION}

\section{Alternative inflation target}

In the first exercise, we changed the monetary authority's inflation target to analyze an alternative path. The growth rate of productive capacity, the inflation rate, the real interest rate, the real exchange rate, and the output gap. 
Figure 1. Growth rates of productive capacity $\left(\mathrm{g}^{*}\right)$ with different inflation targets.

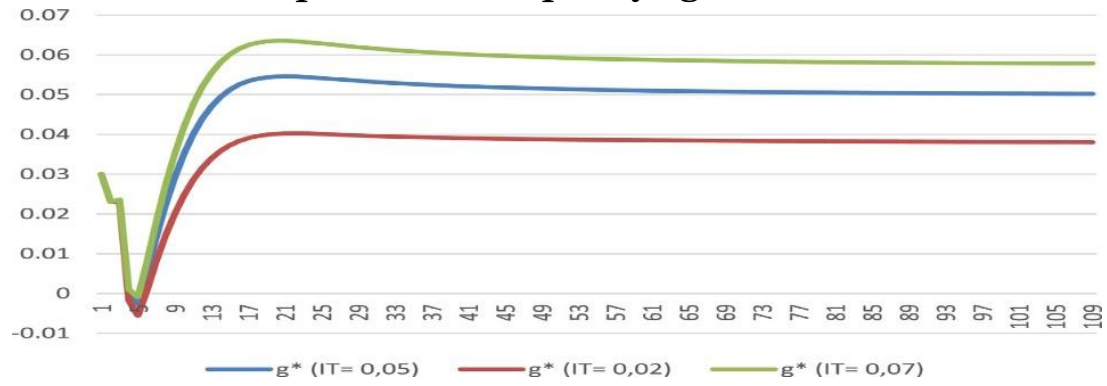

Figure 1 shows the growth rate of the capacity path to different inflation targets $(2 \%, 5 \%$, and $7 \%)$. As expected, a lower inflation target will result in, as a by-product, a lower rate of growth in productive capacity.

Figure 2. Inflation rate dynamics with different inflation targets

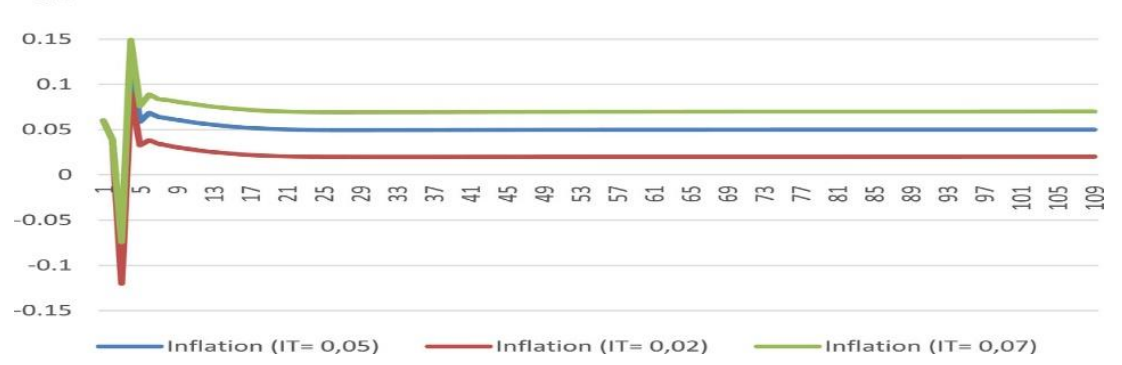

Inflation dynamics with different inflation targets are showed in Figure 2. It is interesting to note that the Monetary Authority can achieve the inflation rate target in the three cases. It means that, even in an economy where the core inflation is costpushed and related to imported inflation, it is possible to the Monetary Authority to control inflation rate using nominal interest as the only policy instrument.

Figure 3. Real interest rate $(r)$ with different inflation targets.

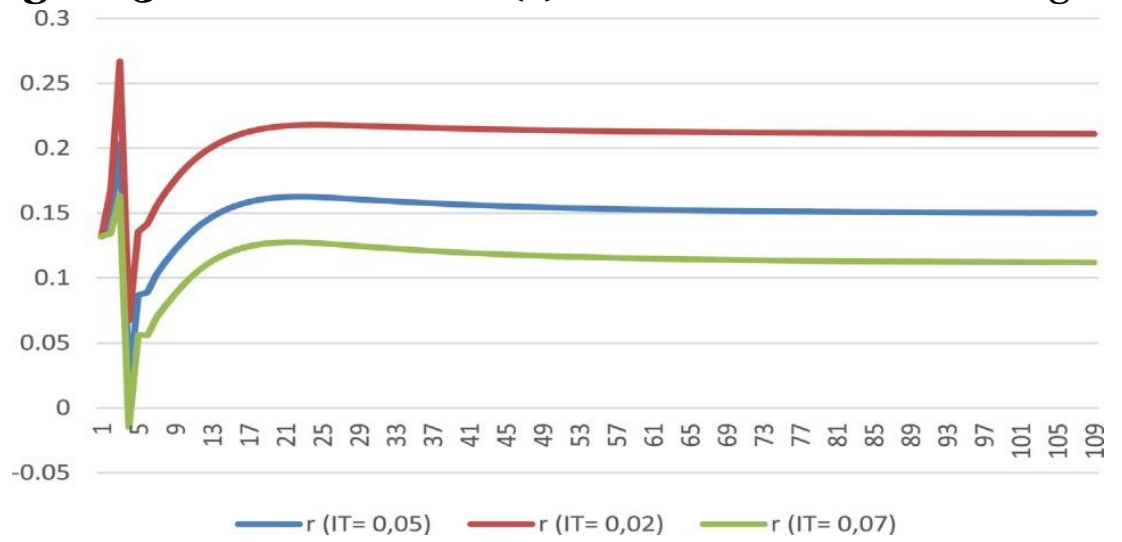

Figure 3 shows the dynamic paths of the real interest rate. Notice that this figure is related to Fig. 1 discussed above. It shows that when the inflation target is lower, the Monetary Authority must set a higher nominal interest rate, resulting in a higher expost real interest rate (higher nominal rate plus lower inflation rate), and this will lead to lower growth rates of productive capacity. 
Figure 4. Output gap with different inflation targets.

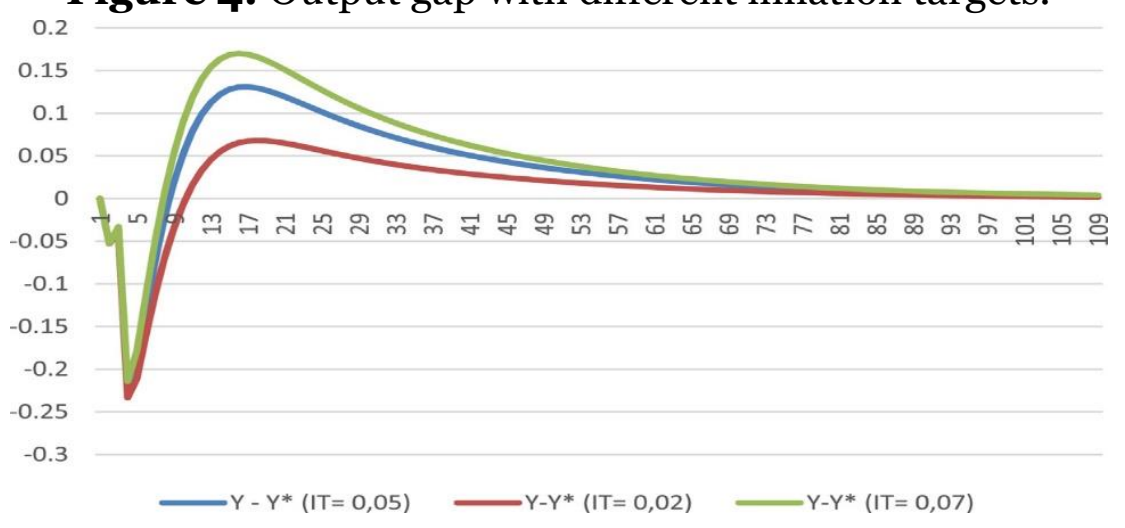

Output gap behavior is showed in Fig. 4. We can see that the output gap endogenously tends to close in all three cases, although it will take longer to converge when the inflation target (and so growth rates of productive capacity) is higher.

Figure 5. Real exchange rate with different inflation targets.

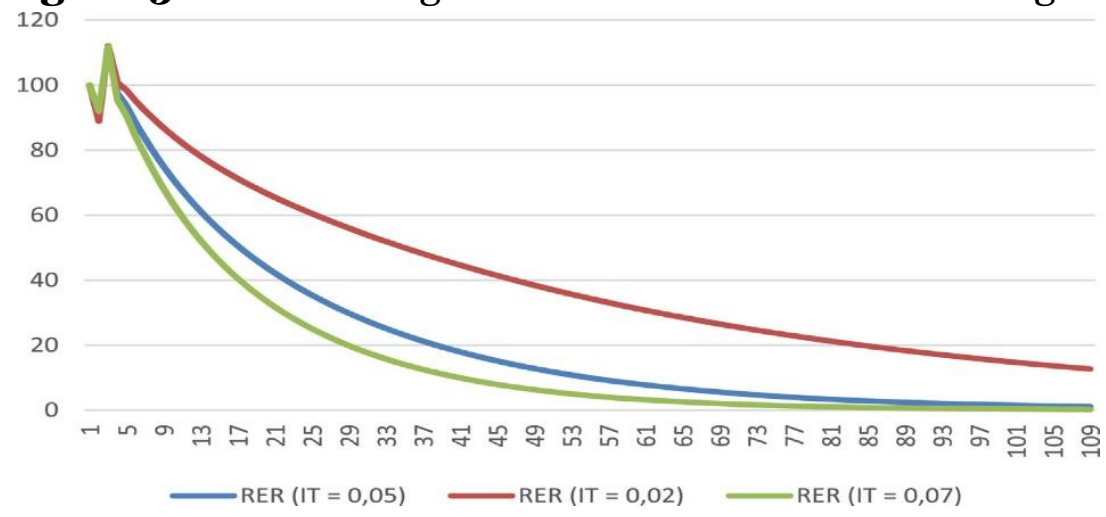

We can see in Figure 5 the path of the real exchange rate. The result shows that, given that this domestic economy faces international inflation and has an inflation target, the nominal exchange rate will appreciate more than inflation differential, resulting in real exchange rate appreciation. Note that this occurs to the three different inflation targets. The higher is the inflation target, the higher will be inflation differential, and this will lead to a quicker process of real exchange rate appreciation.

The final point is that all results are taken with the monetary policy rule parameter $\gamma=0.7$. Even with this parameter, inflation converges with the target when the MA sets the nominal rate of domestic interest. This result can be considered confusing for those who believe in the 'new consensus model' relationship because in this model the parameter $\gamma$ must be greater than that, that is, the nominal interest rate must increase by more than the difference between inflation and the inflation target, to guarantee changes in the interest rate-real estate in the right direction. The bottom line is that in the 'new consensus model,' the MA must change the real interest rate to influence the output gap and control demand-driven inflation pressure. In our model, the transmission mechanism is from the nominal interest rate - through the difference between the nominal interest rate and the nominal international interest rate plus sovereign spread - to the nominal exchange rate, which adaptive expectations can lead to a nominal valuation process exchange rate (or depreciation) and affect inflation. All 
the time. Thus, it is easy to understand that a change in the nominal interest rate, even if it first coincides with a change in the real interest rate in the opposite direction, can control inflation.

\section{International Inflation}

We are exercising another exercise that changes international inflation and monitors results in terms of various international inflation. The growth rate of productive capacity concerning changes in international inflation rates is illustrated in Figure 6. If the economy faces lower international inflation, given the inflation target, the growth rate for productive capacity will be higher then if it faces high inflation international inflation. This is because the MA requires less effort to estimate the nominal exchange rate, and the MA requires a lower interest rate differential, which results in a lower real interest rate and, consequently, a higher interest rate. Increase production capacity.

Figure 6. Growth rates of productive capacity $\left(g^{*}\right)$ with different international

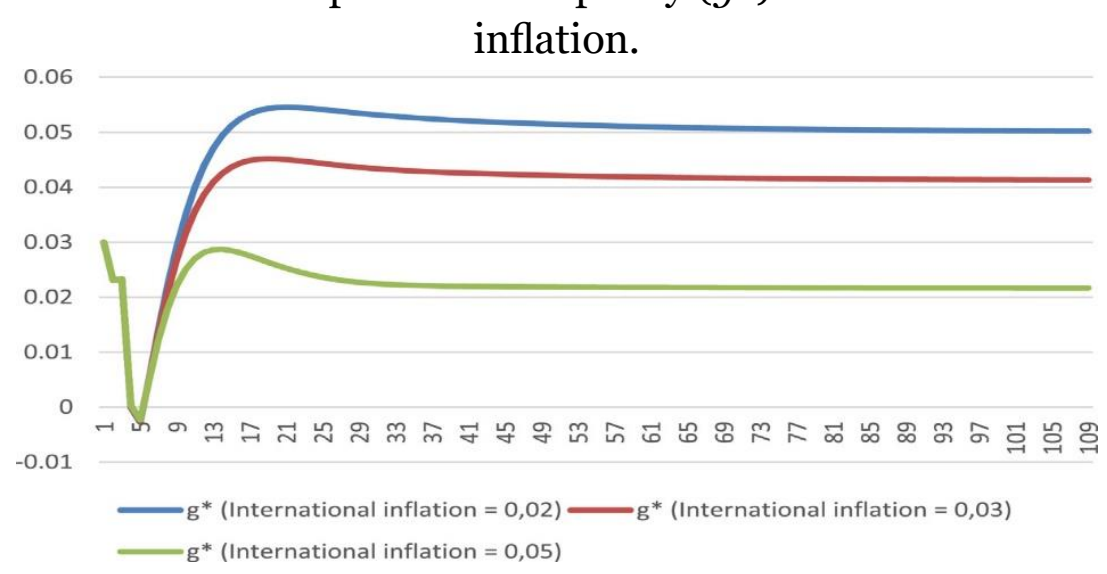

These results draw attention to other ways of interpreting external constraints in a demand-driven growth model. This means that demand-driven increase in production capacity may be constrained by economic policy objectives (in this case, the inflation target) depending on external conditions (in this case, international inflation)

\section{The Level of International Importance and The Spread of Sovereignty}

The same result is obtained when we change international interest rates (or the spread of countries), pointing to another source of constraints to demand-driven growth due to external conditions when a country seeks economic policy objectives. In this case, an increase in international interest rates caused, for example, an autonomous change in US monetary policy, or an increase in the spread of sovereignty of the country as a result of worsening conditions of international liquidity, will result in an increase in levels. production capacity (see Figure 7). This is because, to maintain the same interest rate margin, MAMust needs to raise domestic interest rates, with the consequence of effective demand and production capacity. 
Figure 7. Growth rates of productive capacity $\left(g^{*}\right)$ with different sovereign spread.

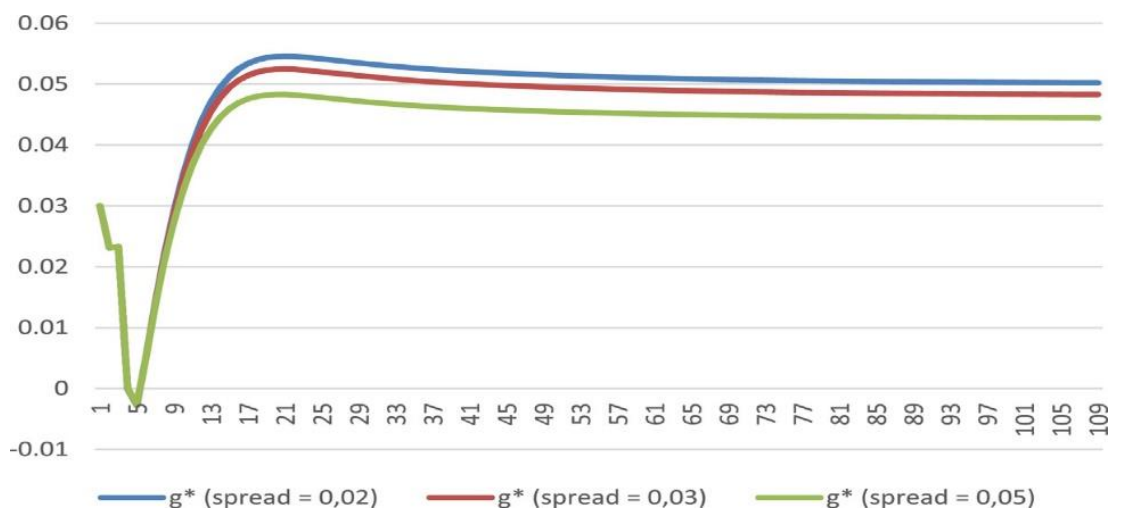

\section{Functional Distribution of Income}

In Figure 8 we can see the results of the functional distribution of income for different inflation targets. The bottom line is that the higher the inflation target, the higher the wages in income. This happens for two reasons: (1) Real interest rates will be lower when the inflation target is higher, and this will lead to lower rates of return in the long run; (2) The real exchange rate appreciates faster when the inflation target is higher, which lowers the price level and thus increases real wages.

Figure 8.. Wage share $(w)$ with different inflation targets.

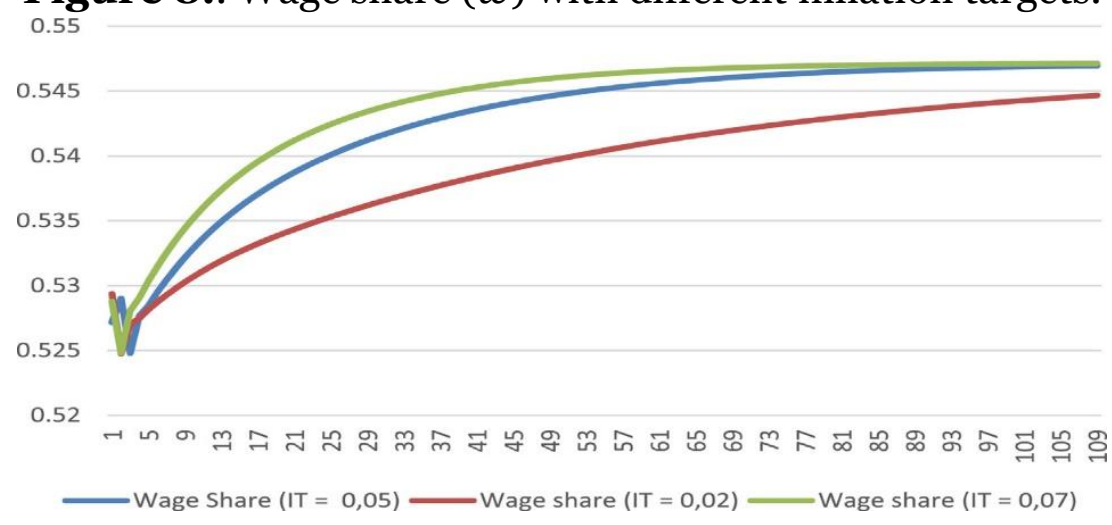

\section{Several limitations to control in this framework}

To date, we have discussed external constraints on demand-driven productive capacity growth, namely, given that in some cases international inflation (or international interest rates) the rate of productive capacity growth will be lower, as a byproduct of achieving the predetermined inflation target. Previous. However, we also need to consider the impossibility of an MA in achieving ASI targets, depending on the country's external conditions, or because of international conditions in general. As discussed earlier, given global inflation, the only way for a country to seek an inflation target when costs drive inflation is to continually appreciate the nominal exchange rate.

However, countries can sometimes face increasing sovereign spreads to finance current account deficits or even international credit rationing (Serrano and Summa, 2015) for exogenous (worsening conditions on international credit markets and 
international credit rationing around the world) or endogenous (increasing in the long term). Short foreign debt, for example) reasons. If this happens, the MA can lose control in attracting short-term capital flows, and MA can be forced to leave IT due to the volatile exchange rate depreciation process.

Other limitations to controlling asi control can arise from political clashes over different groups. For example, some organized political groups that depend on competitive exchange rates (to export their goods and services) can oppose the real exchange rate appreciation process. If they succeed in stopping the appreciation process, inflation will not join the appreciation process. Target. It is important to note that this impossibility of reaching TI can occur even if the MA has 'full credibility.' It is not a question of credibility, but external conditions or 'structural' politics. There are limitations in implementing these policies, which depend on external, political, and institutional factors.

\section{CONCLUSION}

A very important issue about demand-led growth macroeconomic models regards the possible constraints to this kind of growth. The sraffian supermultiplier states that, assuring the stability conditions, capacity output growth respond to and is sufficient to meet effective demand. One possible constraint to demand-led growth could be balance-of-payment long run sustainability, and there is a vast tradition of models following the Kaldor-Thirlwall approach that deals with this issue.

However, and this is an insight which can be obtained from the model presented here, even if there is external room for demand-led growth, some other constraints to the growth of autonomous components of effective demand could appear.

The kind of constraint we explored in this paper is related to the imposition of macroeconomic policy targets

(for example, inflation target or a target of primary surplus/GDP) by policy makers. This can influence the growth rate of autonomous spending, and thus of the productive capacity. So, we can say that the demand-led growth model presented here is constrained by economic policy. Also, this constraint depends mainly on the evolution of country's external accounts, the international credit market conditions and international inflation.

The long-run costs of pursuing such policy were evaluated in terms of rate of growth of productive capacity and functional income distribution to different inflation targets. First, the policy of inflation control is not neutral in terms of growth rate of productive capacity, since controlling inflation through the nominal exchange rate appreciation needs a positive interest rate differential, and, as a result, it impacts on the real interest rate and output/capacity growth rates. Hence, a higher inflation targeting or a lower imported inflation ultimately leads to a higher growth rate of Productive capacity.

Finally, the anti-inflationary policy is not neutral in terms of functional income distribution. Since the distribution depends on the real interest rate and real exchange 
rate, a lower inflation target will lead to higher real interest rates and, consequently, the income distribution will change, reducing the wage share.

Thus, in the model presented here the international inflation has a role in influencing the long run growth rate of productive capacity. This occurs because when the economy experiences a raise in the international inflation, it impacts on the long run domestic inflation, and the Monetary Authority reacts raising the interest rate differential to appreciate the nominal exchange rate faster, in order to reach the inflation target. A higher real interest rate is a by-product of such policy, and has consequences on lowering the growth rate of current output and productive capacity. The external constraint thus can appear in the form of higher imported inflation.

It is important to notice that there can be limitations to operating such policies. This depends on a country political and external conditions and international conditions in general, since the policy of inflation control depends largely on a process of nominal exchange rate appreciation, and this depend on the capacity of MA to set nominal interest rate and attract short run financial flows. The success of this policy will ultimatelly depends on the country's external solvency and liquidity conditions and also on the international credit market conditions.

Finally, it is worth noticing that we are not proposing here a rule of thumb or a stable and well-defined set of choices between economic policy objetives (inflation target) and outcomes (growth rate of productive capacity and functional income distribution). What we want to call atention is that in an open-economy, in which growth rate of productive capacity is demand-led and MA follows some explicit economic policy objectives (like inflation target), there will be real costs in achieving policy targets, and these costs will depend on external conditions.

\section{REFERENCES}

Adams, J. G., \& Walss, R. M. (2020). Supporting the Health Care Workforce During the COVID-19 Global Epidemic (Vol. 60611). https://doi.org/10.1001/jama.2020.3972

Ahmed, A. D., Cheng, E., \& Messinis, G. (2010). The Role of Exports , FDI and imports in development: Evidence from Sub-Saharan African countries The role of exports , FDI and imports in development: evidence from Sub-Saharan African countries. January 2014, 37-41. https://doi.org/10.1080/00036841003705303

Aspromourgos, T., 2007. Interest as an artefact of self-validating central bank beliefs. Metroeconomica 58 (4), 514-535

Atesoglu, H., Smithin, J., 2006. Inflation targeting in a simple macroeconomic model. J. Post Keynesian Econ. 28 (4), 673-688.

Bedford, J., Enria, D., Heyman, D. L., Lhekweazu, C., Kobinger, G., Lane, H. C., Memish, Z., Oh, M.-D., Sall, A. A., Schucat, A., Ungchusak, K., \& Wieler, L. H. (2020). Comment COVID-19: towards controlling of a pandemic. 2019(20), 2019-2021. https://doi.org/10.1016/So140-6736(20)30673-5

Bernanke, B. S., \& Gertler, M. (1995). Inside the Black Box: The Credit Channel of Monetary Policy Transmission. 9(4), 27-48. 
Beutler, T., Bichsel, R., Bruhin, A., \& Danton, J. (2020). The impact of interest rate risk on bank lending. 115. https://doi.org/10.1016/j.jbankfin.2020.105797

Boediono, 1985, Ekonomi Moneter seri sinopsis Pengantar Ilmu Ekonomi Moneter No. 5, Edisi Ketiga,Yogyakarta: Penerbit BPFE Yogyakarta.

Carlino, G. (1999). The Differntial Regional Effects Of Monetary Policy : Evidence From The U. S . States. 39(2), 339-358.

Carrasco, J. J. M., Kallosh, R., \& Linde, A. (2015). Cosmological attractors and initial conditions for inflation. o63519(September), 1-18. https://doi.org/10.1103/PhysRevD.92.063519

Clements, B., Kontolemis, Z. G., \& Levy, J. (2001). Monetary policy under EMU Differences in the transmission mechanism.

Cordero, J., 2008. Economic growth under alternative monetary regimes: inflation targeting vs real exchange rate targeting. Int. Rev. Appl. Econ. 22 (2), 145-16o.

Gertler, M., \& Karadi, P. (2015). Monetary Policy Surprises, Credit Costs, and Economic Activity. 7(1), 44-76.

Gugus Tugas, C.-19. (2020). Data Sebaran. https://covid19.go.id/ Update o2 Agustus 2020

Hanson, S. G., Stein, J. C., \& Hanson, S. G. (2014). Monetary policy and long-term real rates. Journal of Financial Economics. https://doi.org/10.1016/j.jfineco.2014.11.001

Heidenreich, B., Reece, M., \& Rudelius, T. (2015). Weak gravity strongly constrains large-field axion inflation. 12. https://doi.org/10.1007/JHEP12(2015)108

Holmes, E. A., Connor, R. C. O., Perry, V. H., Tracey, I., Wessely, S., Arseneault, L., Ballard, C., Christensen, H., Silver, R. C., Everall, I., Ford, T., John, A., Kabir, T., King, K., Madan, I., Michie, S., Przybylski, A. K., Shafran, R., Sweeney, A., ... Bullmore, E. (2020). Position Paper Multidisciplinary research priorities for the COVID-19 pandemic : a call for action for mental health science. The Lancet Psychiatry, o366(20), 1-14. https://doi.org/10.1016/S2215-0366(20)30168-1

Jawas, M. (2008). Pengaruh Penanaman Modal Asing dan Ekspor Terhadap Pertumbuhan Ekonomi di Negara - Negara Muslim: 2004-2005. Yogyakarta: Fakultas Ekonomi Universitas Islam Indonesia.

Kallosh, R., \& Linde, A. (2015). Inflation and uplifting with nilpotent superfields. 01. https://doi.org/10.1088/1475-7516/2015/01/025

Kearney, J., Yoo, H., \& Zurek, K. M. (2015). Is a Higgs vacuum instability fatal for high-scale inflation? 123537, $1-14$. https://doi.org/10.1103/PhysRevD.91.123537

Krisharianto, Josep, \& D, H. (2007). Kajian Hubungan antara Pertumbuhan Ekonomi, Perdagangan Internasional dan Foreign Direct Investment. Fakultas Ekonomi, Universitas Indonesia.

Lavoie, M., 2006. A post-Keynesian amendment to the new consensus on monetary policy. Metroeconomica 57 (May (2)), 165-192

Lavoie, M., Kriesler, P. , 2007. The new view on monetary policy: the new consensus and its post-Keynesian critique. Rev. Polit. Econ. 19 (3), 387-404.

Malmendier, U., \& Nagel, S. (2015). Learning From Infaltion Expereinces. The 
Quarterly Journal of Economics Advance, Oktober.

Marco, B., Negro, D., Giannoni, M. P., \& Schorfheide, F. (2015). Inflation in the Great Recession and New Keynesian Models. 7(1), 168-196.

Meng, L., Hua, F., \& Bian, Z. (2020). Coronavirus Disease 2019 ( COVID-19): Emerging and Future Challenges for Dental and Oral Medicine. 2019. https://doi.org/10.1177/0022034520914246

Motohashi, H., Starobinsci, A. A., \& Yokoyama, J. (2015). Inflation with a constant rate of roll. Jurnal of Cosmology And Astoparticle Physic, o9. https://doi.org/10.1088/1475-7516/2015/o9/018

Nopirin. 2000. Ekonomi Moneter, Buku I dan II. Yogyakarta : BPFE UGM.

Nowbutsing, B. M. (2014). The Impact of Openness on Economic Growth: Case of Indian Ocean Rim Countries. Journal of Economics and Development Studies, 2(2), 407-427.

Oda, K. (2015). Higgs inflation from standard model criticality. O530o8, 1-18. https://doi.org/10.1103/PhysRevD.91.053008

Owyang, M. T., \& Wall, H. J. (2005). Structural Breaks and Regional Disparities in the Transmission of Monetary Policy.

Ramaswamy, R., \& Slok, T. (1998). The Real Effects Of Monetary Policy In The European Union: What Are The Differences.

Saraswat, P., \& Sundrum, R. (2015). Natural Inflation and Quantum Gravity. 151303(April), 1-6. https://doi.org/10.1103/PhysRevLett.114.151303

Serrano, F., Mimeo 2006. Mind the Gap: Hysteresis, Inflation Dynamics and the Sraffian Supermultiplier. IE-UFRJ.

Setterfield, D.M., 2015. Won't Get Fooled Again - Or Will We? Monetary Policy, Model Uncertainty, and 'Policy Model Complacency'. Monetary Policy, Model Uncertainty, and 'Policy Model Complacency'.

Setterfield, M., 2004. Central banking, stability and macroeconomic outcomes: a comparison of newconsensus and post-Keynesian monetary macro economics. In: Lavoie, M., Secareccia, M. (Eds.), Central Banking in the Modern World: Alternative Perspectives. Edward Elgar, Cheltenham, pp. 35-56.

Shahzad, M. I. (2017). Causality Relationship between Foreign Direct Investment , Trade and Economic Growth in Pakistan. Asian Social Science, 6(9), 82-89.

Spinelli, A. (2020). COVID-19 pandemic : perspectives on an unfolding crisis. 785787. https://doi.org/10.1002/bjs.11627

Summa, R. (2016). An alternative model to the open-economy " new consensus " for the analysis of inflation targeting. EconomiA, 17(3), 310-323. https://doi.org/10.1016/j.econ.2016.09.007

Tillmann, P. (2019). Monetary Policy Uncertainty and the Response of the Yield Curve to Policy Shocks. oo(o). https://doi.org/10.1111/jmcb.12657

Vera, L., 2014. The simple post-Keynesian monetary policy model: an open economy approach. Rev. Polit. Econ. 26 (4), 526-548. 